\title{
Methylene blue associated with maghemite nanoparticles has antitumor activity in breast and ovarian carcinoma cell lines
}

\author{
Ana Luísa G. Silva', Natália V. Carvalho', Leonardo G. Paterno², Ludmilla D. Moura³ ${ }^{3}$ Cleber L. Filomeno², \\ Eneida de Paula ${ }^{3}$ and Sônia N. Báo ${ }^{1 *}$ (D)
}

\author{
${ }^{*}$ Correspondence: \\ snbao2009@gmail.com \\ ${ }^{1}$ Department of Cell Biology, \\ Institute of Biological \\ Sciences, University \\ of Brasília, Brasília, DF, Brazil \\ Full list of author information \\ is available at the end of the \\ article
}

\begin{abstract}
Background: Cancer constitutes group of diseases responsible for the second largest cause of global death, and it is currently considered one of the main public health concerns nowadays. Early diagnosis associated with the best choice of therapeutic strategy, is essential to achieve success in cancer treatment. In women, breast cancer is the second most common type, whereas ovarian cancer has the highest lethality when compared to other neoplasms of the female genital system. The present work, therefore, proposes the association of methylene blue with citrate-coated maghemite nanoparticles (MAGCIT-MB) as a nanocomplex for the treatment of breast and ovarian cancer.

Results: In vitro studies showed that T-47D and A2780 cancer cell lines underwent a significant reduction in cell viability after treatment with MAGCIT-MB, an event not observed in non-tumor (HNTMC and HUVEC) cells and MDA-MB-231, a triple-negative breast cancer cell line. Flow cytometry experiments suggest that the main mechanism of endocytosis involved in the interiorization of MAGCIT-MB is the clathrin pathway, whereas both late apoptosis and necrosis are the main types of cell death caused by the nanocomplex. Scanning electron microscopy and light microscopy reveal significant changes in the cell morphology. Quantification of reactive oxygen species confirmed the MAGCIT-MB cytotoxic mechanism and its importance for the treatment of tumor cells. The lower cytotoxicity of individual solution of maghemite nanoparticles with citrate (MAGCIT) and free methylene blue (MB) shows that their association in the nanocomplex is responsible for its enhanced therapeutic potential in the treatment of breast and ovarian cancer in vitro.
\end{abstract}

Conclusions: Treatment with MAGCIT-MB induces the death of cancer cells but not normal cells. These results highlight the importance of the maghemite core for drug delivery and for increasing methylene blue activity, aiming at the treatment of breast and ovarian cancer.

Keywords: Iron oxide nanoparticles, Cytotoxicity, Antitumor effect, ROS included in the article's Creative Commons licence and your intended use is not permitted by statutory regulation or exceeds the permitted use, you will need to obtain permission directly from the copyright holder. To view a copy of this licence, visit http://creativecommons.org/ licenses/by/4.0/. The Creative Commons Public Domain Dedication waiver (http://creativecommons.org/publicdomain/zero/1.0/) applies to the data made available in this article, unless otherwise stated in a credit line to the data. 


\section{Background}

Cancer, a group of diseases responsible for the second most significant number of global deaths, is considered one of the main public health concerns nowadays (Siegel et al. 2018). According to WHO data, it is estimated that one out of six deaths worldwide is caused by neoplasms (World Health Organization (2018)). Among the cancer types most prevalent in women, breast cancer is the second highest cause of death, whereas ovarian cancer is, the deadliest of gynecological cancers (McKinney et al. 2020; Yang et al. 2020). Currently, common therapeutic procedures used to combat these diseases, including surgery, chemotherapy, and radiotherapy, may not promote complete eradication of tumor cells and usually cause damage to normal cells, thereby resulting in adverse alterations and compromising the patient's health and quality of life (Boero et al. (2019); Widianti et al. 2019). Therefore, the search for and development of new treatments to effectively combat breast and ovarian carcinomas has been the focus of several studies (Goldberg 2019; Tran et al. 2019; Li et al. 2020).

Most studies concerning the fight against cancer aim, to increase the local production of reactive oxygen species (ROS) (Hayes et al. 2020). Current studies show evidence of the involvement of ROS in the regulation of numerous signaling pathways that control important biological processes related to the promotion and progression of carcinogenesis, such as migration, differentiation, proliferation and even adaptation to oxidative stress (Reczek and Chandel 2017). However, it has been proven that high levels of ROS can increase oxidative stress, and this leads to interruption of the cell cycle, induces cell senescence, and ultimately causes cancer cell death (Hayes et al. 2020; Reczek and Chandel 2017). The use of nanomaterials for promoting cell death by means of oxidative stress via ROS has gained a lot of prominence over the last few years, since cancer cells have high levels of ROS compared to normal cells, and thus become more vulnerable to cell death induced by oxidative stress (Reczek and Chandel 2017). Different strategies may be applied to this end, especially those involving photodynamic therapy (PDT). When excited by an external energy source, usually in the visible range, the photosensitizer transfers the absorbed energy to surrounding oxygen molecules, which are thus converted from triplet to singlet state, which triggers ROS production (Sadeghloo et al. 2020). Despite its efficient dynamics, the practical use of PDT demands a delivery vehicle capable of transporting and making the photosensitizer available in the tumor site, otherwise its therapeutic efficiency is undermined.

Methylene blue (MB) is a hydrophilic photosensitizer exhibiting a wide light absorption window in the range of red light $(550-700 \mathrm{~nm})$ and with a maximum absorption peak at $660 \mathrm{~nm}$ (Cwalinski et al. 2020). It has long been employed in microbiological staining and, more recently, as photosensitizer in PDT, mainly through production of singlet oxygen, with a quantum yield of 0.52 (Tardivo et al. (2005)). However, one of its shortcomings in biomedical applications is the loss of therapeutic efficiency by direct administration. Its association with drug delivery platforms is, therefore, mandatory to harness its full therapeutic potential (Rozecholc et al. 2019; Santos et al. 2018; Yaroslavisky et al. 2019). Graphene oxide nanosheets, for example, have made the delivery of MB to tumor cells possible, ensuring simultaneously availability and efficiency (Santos et al. 2018). 
Among the available delivery platforms, iron oxide nanoparticles (IONs) have shown a tremendous impact on tumor diagnosis and therapies, owing to intrinsic superparamagnetism alongside accessible surface chemistry and low cytotoxicity. IONs mainly comprising magnetite $\left(\mathrm{Fe}_{3} \mathrm{O}_{4}\right)$ and maghemite $\left(\gamma-\mathrm{Fe}_{2} \mathrm{O}_{3}\right)$ have been successfully applied as contrast agents for magnetic resonance imaging as well as platforms for delivering antineoplastic drugs and magnetically induced hyperthermia techniques (Ayyanaar et al. 2020; Malhotra et al. 2020; Mirza et al. 2020). Besides the high surface-to-volume ratio, IONs are capable of crossing the tumor cell membranes and are retained in the tumor tissue (Carneiro et al. 2013; Shojaee et al. 2019). Although many potential antitumor drugs, such as doxorubicin or rhodium citrate, have been conjugated onto IONs for therapeutic studies, to the best of our knowledge MB associated with IONs has never been investigated. Thus, the present work proposes a novel platform for the therapy of breast and ovarian tumor cell lines encompassing $\mathrm{MB}$ associated with citrate-coated maghemite nanoparticles (MAGCIT-MB) by simple electrostatic interaction. The association of these two components in a single nanocomplex is an attractive strategy, since IONs and $\mathrm{MB}$ are both inexpensive compounds, and have proven to play independent roles in antitumor therapies. However, $\mathrm{MB}$ is water-soluble and can easily migrate through the body without reaching the targeted organ. Immobilization onto drug-delivery platforms is, therefore, the strategy to overcome this drawback and to harness its main advantage over actual drugs, namely cost. Similarly to what happened when MB was associated with graphene oxide (Sahu et al. 2013), its association with MAGCIT is mainly driven by electrostatic interaction. Citrate groups located on the MAGCIT surface are, however, weak acids and, therefore, their ionization degree is susceptible to $\mathrm{pH}$ changes. It is well-known that the $\mathrm{pH}$ in the environment of tumor cells is a lightly acidic, being therefore capable of shifting the equilibrium of unprotonated-protonated citrate moieties, which ultimately causes the release of MB molecules. Therefore, association of MB with MAGCIT through electrostatic interaction increases its availability to the target tumor. In addition, the surface of MAGCIT is mainly composed of Fe (III) oxyhydroxides, which are responsible for change-transfer processes that cycle iron between its two common oxidation states. In this process, MB radicals are thus formed and, as reviewed by Tardivo et al. (2005), they may react with molecular oxygen forming superoxide, which in the presence of Fe (III) produces hydroxyl radical through the Fenton reaction, thereby increasing the ROS concentration in the tumor environment.

\section{Results and discussion}

\section{Characterization of the MAGCIT-MB nanosystem}

MAG was first functionalized with sodium citrate followed by electrostatic adsorption of cationic MB. As shown in Table 1, MAGCIT-MB zeta potential (ZP) and hydrodynamic diameter (HD) increased as the concentration of MB in the adsorption solution increased. Although ZP increased, it was still negative, which favors the endocytosis of the nanomaterial in several ways (Blanco et al. 2015; Fröhlich 2012). The increase of $Z P$ is assigned to the neutralization of some citrate groups by adsorption of cationic MB molecules, which also increases HD. Aiming at the lowest $\mathrm{HD}$ and the highest concentration of MB available in MAGCIT-MB, the suspension numbered as 3 was chosen for the development of the work, since it exhibited 
Table 1 Physicochemical properties of the nanomaterial

\begin{tabular}{llll}
\hline Samples & HD $(\mathbf{n m})$ & Pdl & ZP $(\mathbf{m V})$ \\
\hline MAGCIT $(\mathrm{pH} 6.6)$ & $54.69 \pm 0.08$ & $0.185 \pm 0.014$ & $-31.9 \pm 1.58$ \\
MAGCIT-MB & & & \\
Solution 1 $(11 \mu \mathrm{g} / \mathrm{mL})$ & $54.02 \pm 0.70$ & $0.243 \pm 0.021$ & $-30.5 \pm 2.69$ \\
Solution 2 $(20 \mu \mathrm{g} / \mathrm{mL})$ & $63.06 \pm 0.55$ & $0.211 \pm 0.027$ & $-31.0 \pm 1.72$ \\
Solution 3 $(31 \mu \mathrm{g} / \mathrm{mL})$ & $60.93 \pm 0.36$ & $0.199 \pm 0.009$ & $-20.9 \pm 2.00$ \\
Solution $4(53 \mu \mathrm{g} / \mathrm{mL})$ & $135.00 \pm 1.32$ & $0.166 \pm 0.010$ & $-26.5 \pm 1.55$
\end{tabular}

MAGCIT: solution of maghemite nanoparticles with citrate; MAGCIT-MB: maghemite nanoparticles with citrate and methylene blue; HD: hydrodynamic diameter; Pdl: polydispersity index; ZP: zeta potential

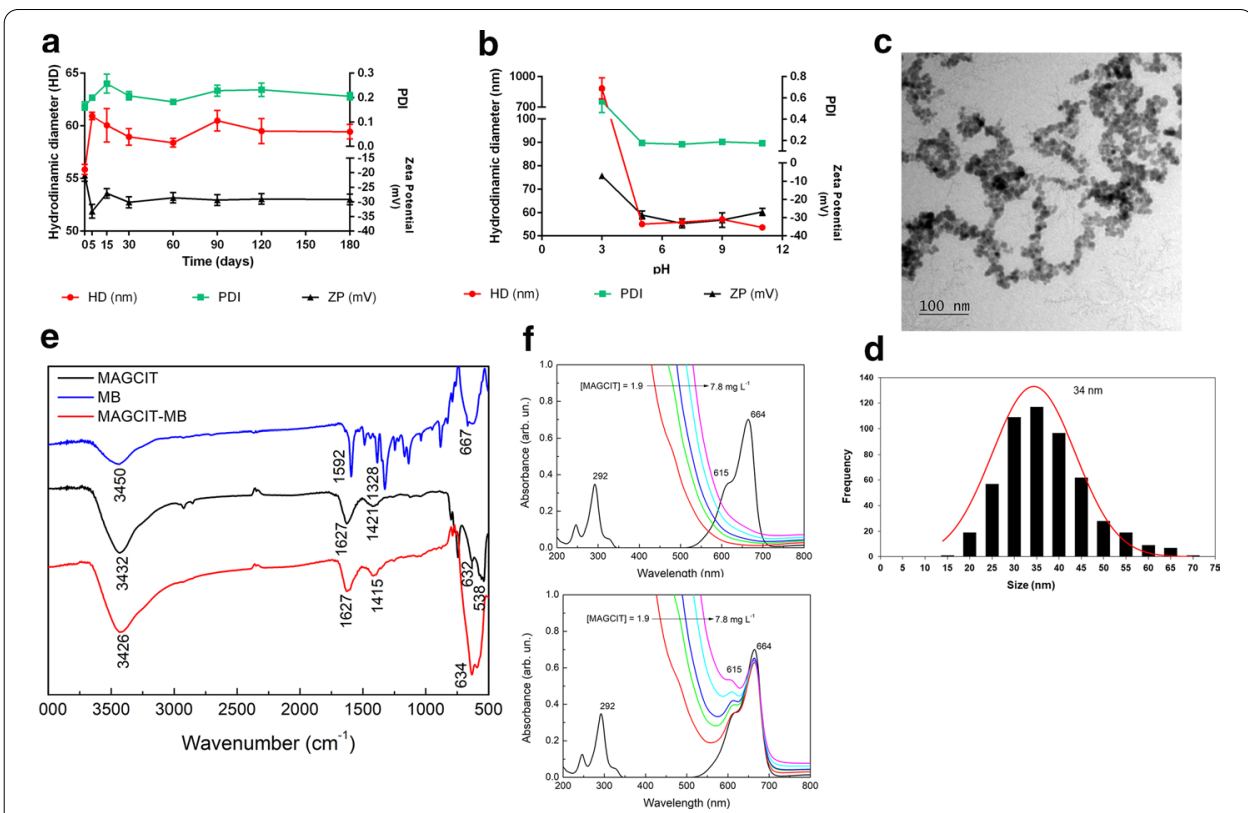

Fig. 1 MAGCIT-MB ultrastructure and characterization. $\mathbf{a}$, b Colloidal stability of MAGCIT-MB, Hydrodynamic diameter (HD), zeta potential (ZP) and polydispersity index (PDI) over 180 days (a) and pH variation (b) measured by dynamic light scattering. c Rounded morphology of MAGCIT-MB assessed by TEM at $80 \mathrm{kV}$. Scale bar $=100 \mathrm{~nm}$. $\mathbf{d}$ Nanoparticle size distribution of MAGCIT-MB had an average size of $34 \pm 9 \mathrm{~nm}$; measurements were performed using ImageJ software. e FTIR spectra of MB, MAGCIT and MAGCIT-MB. $\mathbf{f} U$ Vis spectra of individual MAGCIT suspensions at different concentrations $\left(7.8 \mathrm{mg} \mathrm{L}^{-1}, 5.8 \mathrm{mg} \mathrm{L}^{-1}, 3.9 \mathrm{mg} \mathrm{L}^{-1}\right.$, $2.9 \mathrm{mg} \mathrm{L}^{-1}$ and $1.9 \mathrm{mg} \mathrm{L}^{-1}$ ) and MB solution (upper panel), and spectra of MAGCIT-MB with different MAGCIT concentrations, as indicated (lower panel)

HD equaling $60.93 \pm 0.36 \mathrm{~nm}$ with a polydispersity index (PDI) of $0.19 \pm 0.01$ and ZP equaling $-20.9 \pm 2.00 \mathrm{mV}$. As shown in Fig. 1a, the HD, ZP and PDI of this sample evaluated at $\mathrm{pH} 3.0,5.0,7.0,9.0$ and 11.0 varied slightly over 180 days of observation, thereby demonstrating its colloidal stability. Indeed, above $\mathrm{pH} 5$, these parameters remained practically unaltered (Fig. 1b). The assessment of the colloidal properties in physiological fluids is important. Thus, we performed these parameters, HD, ZP and PDI, with biological media (Additional file 1: Table S1). HD, ZP and PDI undergo alterations because of protein aggregation and corona formation (Izci et al. 2021). Moore et al. and Izci et al. discuss nanoparticles added to serum, which results in a nanomaterial covered with albumin and other proteins, forming 
the protein corona, which can destabilize the nanoparticles through a change in the surface charge (Izci et al. 2021; Moore et al. 2015).

The transmission electron microscopy (TEM) image of sample 3 (Fig. 1c) reveals nanoparticles of spherical-like shape, corroborating previous studies (Harush et al. 2008; Araujo et al. 2020; Rocha et al. 2017), measuring an average size of $34 \pm 9 \mathrm{~nm}$, the latter being determined from the size distribution fitted by a log-normal function as shown in Fig. 1d. The X-ray diffractogram pattern confirms the inverse spinel structure (Additional file 2: Figure S1a), whereas the most intense diffraction peak (311), allowed us to estimate the lattice parameter. In that case the value found was $0.832 \mathrm{~nm}$, which is compatible with the lattice parameter of maghemite (Schwertmann and Cornell 1991). The Fourier transform infrared spectroscopy (FTIR) analysis of individual components (Fig. 1e) confirmed the expected main functional groups for $\mathrm{MB}\left(\mathrm{OH}\right.$ stretching at $3450 \mathrm{~cm}^{-1}$, due to adsorbed water; $\mathrm{C}=\mathrm{S}^{+}\left(\mathrm{CH}_{3}\right)_{2}$ stretching at $1592 \mathrm{~cm}^{-1} ; \mathrm{C}=\mathrm{S}^{+}$stretching at $1486 \mathrm{~cm}^{-1} ; \mathrm{C}-\mathrm{S}-\mathrm{C} / \mathrm{C}-\mathrm{N}-\mathrm{C}$ stretching at $\left.667 \mathrm{~cm}^{-1}\right)$ and MAGCIT $\left(\mathrm{O}-\mathrm{H}\right.$ stretching at $3432 \mathrm{~cm}^{-1}$; asymmetrical and symmetrical $\mathrm{COO}^{-}$stretching at $1627 \mathrm{~cm}^{-1}$ and $1421 \mathrm{~cm}^{-1}$, and $\mathrm{Fe}-\mathrm{O}$ stretching at 632 and $538 \mathrm{~cm}^{-1}$ ) (Schwertmann and Cornell 1991; Ovschinnikov et al. 2016; Morales et al. 1999). The spectrum of MAGCIT-MB is quite similar to that of MAGCIT, since a low amount of $\mathrm{MB}$ is adsorbed. However, it is worth mentioning that there is a red-shift $\left(6 \mathrm{~cm}^{-1}\right)$ of the symmetrical COO- stretching after adsorption of $\mathrm{MB}$, which is likely due to the electrostatic interaction with MAGCIT. UV-vis spectra of individual MAGCIT at different concentrations and MB solutions are shown in Fig. If (upper chart). The spectra of MAGCIT is structureless, displaying a subtle adsorption at $\sim 480 \mathrm{~nm}$ ascribed to $\mathrm{Fe}(\mathrm{II}) \mathrm{Fe}(\mathrm{III})$ transitions, whereas the MB spectrum exhibited the characteristic B-band at $29 \mathrm{~nm}$ and the Q-band, which is split into a stronger $(660 \mathrm{~nm})$ and a weaker absorption $(615 \mathrm{~nm})$ regarding monomeric and dimeric MB species, respectively (Ovschinnikov et al. 2016) (Fig. 1f). In Fig. If (lower chart), successive addition of MAGCIT to MB increases the ratio between dimeric and monomeric $\mathrm{MB}$ species, suggesting their agglomeration onto the MAGCIT surface.

Although previous analyses have suggested some level of interaction between MAGCIT and MB, a clearer evidence was given further by fluorescence spectroscopy. For a fixed concentration of $\mathrm{MB}\left(3.1 \times 10^{-3} \mathrm{~g} \mathrm{~L}^{-1}\right)$, a monotonic decrease (suppression) of its fluorescence was observed as the concentration of MAGCIT increased (Additional file 2: Figure S1b). To determine whether the suppression was due to chemical (charge-transfer) or physical (inner filter) effects, the same experiment was performed but with MAGCIT and MB sampled in separate cuvettes. The cuvettes were aligned along the light beam, with the cuvette containing MAGCIT placed before that containing MB. The suppression was also observed, but to a much lower extent (Additional file 2: Figure S1c). This outcome suggested that once MB is photoexcited, it transfers charge to MAGCIT, corroborating the mechanism previously described by Katz et al. (2012). It is important to point out that the observed suppression caused by MAGCIT was only partial, and the remaining fluorescence signal of adsorbed $\mathrm{MB}$ was high enough to be explored during subsequent experiments. 


\section{Cell viability studies}

The cytotoxicity of MAGCIT, free MB and MAGCIT-MB was determined from the Alamar Blue $^{\mathrm{TM}}$ assay. As tumor and normal cells they were treated for 24,48 and $72 \mathrm{~h}$ with free MB at 5.0, 2.5, 1.25 and $0.62 \mu \mathrm{g} \mathrm{mL}{ }^{-1}$ and MAGCIT-MB at 3.12, 1.56, 0.78 and $0.39 \mu \mathrm{gL}^{-1}$. Tumor lines A2780 and T-47D were more affected by the developed nanocomplex, with a significant reduction in cell viability in all or three out of four concentrations, respectively (Fig. 2a and c, respectively). For the assay performed with free MB in tumor cells A2780 and T-47D, only the highest concentrations (5.0, 2.5 and $1.25 \mu \mathrm{g} \mathrm{mL}^{-1}$ ) increased the cell death, suggesting a strengthened effect between agents (Fig. 2b and d, respectively). Comparatively, the MDA-MB-231 line showed little or no response to MAGCIT-MB, with the highest percentage (20\%) of reduced cell viability reached solely after $72 \mathrm{~h}$ of treatment (Fig. 2e), whereas it was more sensitive to free MB (Fig. 2f). Although there was no reduction in cell viability, the cell proliferation assay (CFSE) demonstrated that MAGCIT-MB reduces the proliferation of these cells after 48 fours of treatment (Additional file 3: Figure S2). As for non-tumor cells, HUVEC and human non-tumor mesenchymal cell (HNTMC) were, more resistant to MAGCIT-MB treatment, in which a less significant reduction in cell viability was obtained (Fig. $2 \mathrm{~g}$ and i, respectively). Adaptation to excessive ROS levels in cancer cells has been reported, suggesting they have a higher basal ROS level than normal cells (Kim et al. 2019); therefore, treatments that elevate ROS levels break the redox homeostasis and causes cancer cell death, as we can see with MAGCITMB treatment (Rocha et al. 2020). An antagonistic fact is, however, observed after treatment with free $\mathrm{MB}$, in which toxicity levels were subjected to low rates of agents (Fig. $2 \mathrm{~h}$ and $\mathrm{j}$, respectively) The treatment with plain MAGCIT $\left(3,84 \mu \mathrm{g} \mathrm{mL}{ }^{-1}\right)$ did not reduce the viability (below 70\%), of any of the studied cell lines (Additional file 4: Figure S3), suggesting its possible biocompatibility (Schwertmann and Cornell 1991) and a greater potential for application in drug delivery systems considering the interference in activity of free MB. In addition to the short-term viability assays, we tested the efficacy profiles of the MAGCIT-MB in long-term colony formation and cell recovery (Morales et al. 1999), for non-colony cells, in assays and observed similar results (Additional file 5: Figure S4).

Inhibitory Concentration of $50 \%\left(\mathrm{IC}_{50}\right)$, is frequently performed for the fundamental aspects of pharmacology. This value refers to the concentration responsible for the death of $50 \%$ of cells with the treatment proposed (Gomis-Tena et al. 2020; Loutfy et al. 2019). In this experiment, these rates were calculated for all treatment periods in the five cell lines studied. It was observed that the $\mathrm{IC}_{50}$ value decreases over time and concentration, corroborating the cell viability test. Tumor cells showed an increase of $\mathrm{IC}_{50}$ when treated with free $\mathrm{MB}$. On the other hand, these values decreased for non-tumoral cells, therefore indicating the importance of combining $\mathrm{MB}$ with MAGCIT, which may offer a less harmful treatment to normal cells (Wang et al. 2020) (Tables 2 and 3). These results agree with previous studies showing MB selectivity for tumor cells (Tardivo et al. 2005; Santos et al. 2017, 2018). The enhanced efficacy of MAGCIT-MB could be derived from a mechanism of rapid and high permeability mediated by endocytosis, as will be shown by TEM and uptake experiments. 

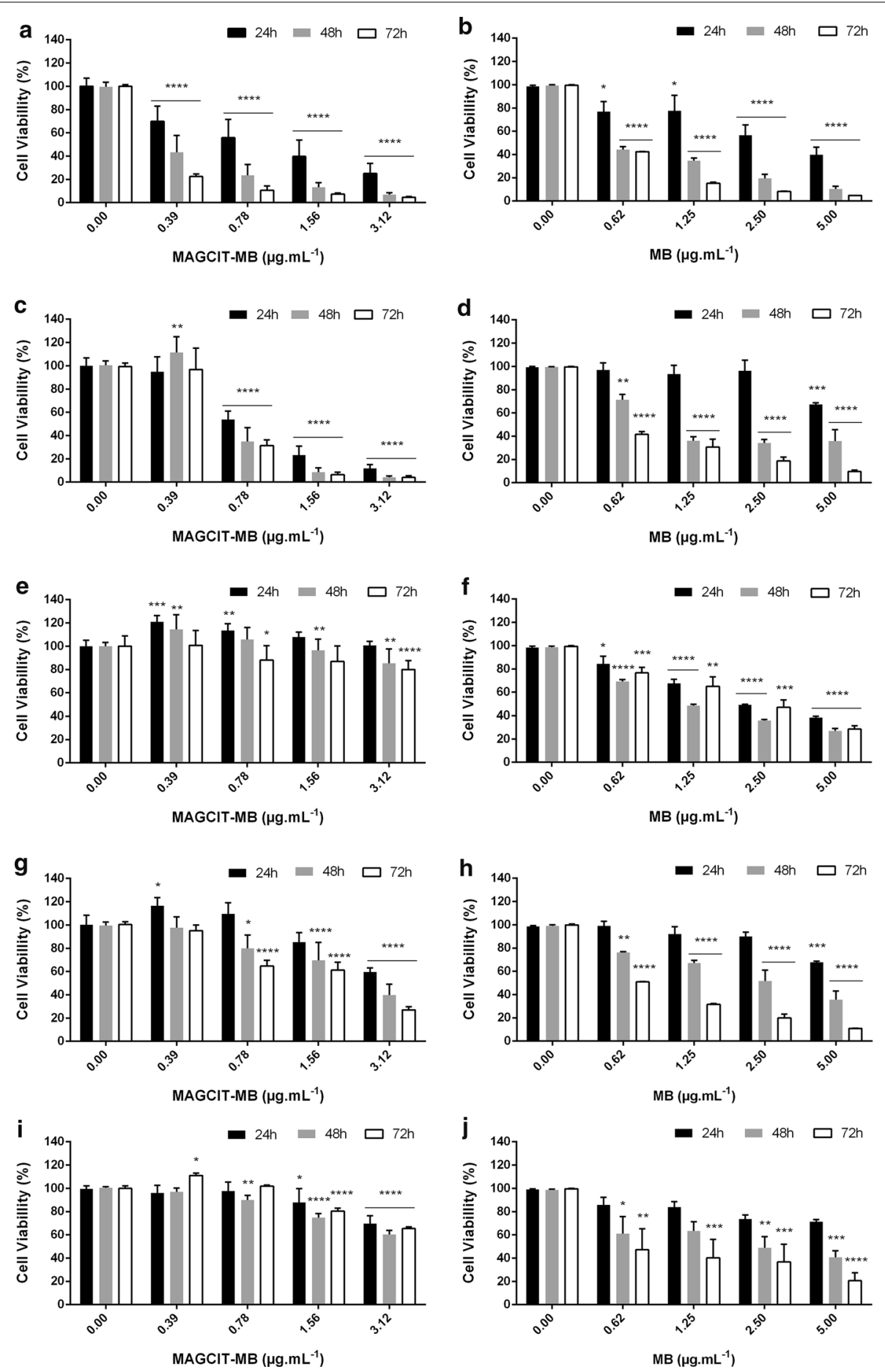

Fig. 2 Cytotoxicity of MAGCIT-MB and free MB after 24, 48 and 72 h. a A2780, c T-47D, e MDA-MB-231, g HUVEC and $\mathbf{i}$ HNTMC cell viability after exposure to MAGCIT-MB. b A2780, d T-47D, f MDA-MB-231, $\mathbf{h}$ HUVEC and $\mathbf{j}$ HNTMC cell viability after exposure to free MB. Bars represent cell viability in percentage after treatments at the indicated concentrations. The data represent the mean \pm SEM of three independent experiments in triplicate. ${ }^{*} p<0.05 ;{ }^{* *} p<0.01,{ }^{* * *} p<0.001$ and ${ }^{*{ }^{* *}} p<0.0001 .{ }^{*}$ Treatment compared to NT control 
Table 2 IC $_{50}$ of MAGCIT-MB for MDA-MB-231, A270, T-47D, HUVEC and HNTMC at 24, 48, $72 \mathrm{~h}$

\begin{tabular}{llll}
\hline Time & $\mathbf{2 4 h}$ & $\mathbf{4 8 h}$ & $\mathbf{7 2} \mathbf{h}$ \\
\hline MDA-MB-231 & $>3.12 \mathrm{\mu g} \mathrm{mL}^{-1}$ & $>3.12 \mu \mathrm{g} \mathrm{mL}^{-1}$ & $>3.12 \mu \mathrm{g} \mathrm{mL}^{-1}$ \\
A2780 & $0.53 \mu \mathrm{g} \mathrm{mL}^{-1}$ & $0.25 \mu \mathrm{gL}^{-1}$ & $0.08 \mathrm{gg} \mathrm{mL}^{-1}$ \\
T-47D & $0.69 \mu \mathrm{g} \mathrm{mL}^{-1}$ & $0.59 \mu \mathrm{gL}^{-1}$ & $0.57 \mathrm{\mu g} \mathrm{mL}^{-1}$ \\
HUVEC & $1.55 \mu \mathrm{g} \mathrm{mL}^{-1}$ & $1.40 \mu \mathrm{gL}^{-1}$ & $1.01 \mathrm{gg} \mathrm{mL}^{-1}$ \\
HNTMC & $1.86 \mu \mathrm{g} \mathrm{mL}^{-1}$ & $1.01 \mu \mathrm{gL}^{-1}$ & $1.24 \mu \mathrm{gL} \mathrm{mL}^{-1}$ \\
\hline
\end{tabular}

Table $3 I_{50}$ of free MB for MDA-MB-231, A270, T-47D, HUVEC and HNTMC at 24, 48, $72 \mathrm{~h}$

\begin{tabular}{llll}
\hline Time & $\mathbf{2 4 h}$ & $\mathbf{4 8 h}$ & $\mathbf{7 2 ~ \mathbf { ~ }}$ \\
\hline MDA-MB-231 & $0.96 \mu \mathrm{g} \mathrm{mL}^{-1}$ & $0.58 \mu \mathrm{g} \mathrm{mL}^{-1}$ & $1.01 \mu \mathrm{g} \mathrm{mL}^{-1}$ \\
A2780 & $1.11 \mu \mathrm{gL}^{-1}$ & $0.38 \mu \mathrm{gL}^{-1}$ & $0.27 \mu \mathrm{gL}^{-1}$ \\
T-47D & $3.37 \mu \mathrm{gL}^{-1}$ & $0.81 \mu \mathrm{gL}^{-1}$ & $0.33 \mu \mathrm{gL}^{-1}$ \\
HUVEC & $2.73 \mu \mathrm{gL}^{-1}$ & $0.17 \mu \mathrm{gL}^{-1}$ & $0.41 \mu \mathrm{gL}^{-1}$ \\
HNTMC & $0.60 \mu \mathrm{gL}^{-1}$ & $0.44 \mu \mathrm{gL}^{-1}$ & $0.56 \mu \mathrm{gL}^{-1}$ \\
\hline
\end{tabular}

\section{Morphological and structural alterations in tumoral and non-tumoral cell lines}

In order to reveal the morphological and structural alterations in cells, phase contrast light microscopy was performed. A2780 and T-47D cells exhibit both spindle and rounded morphology forming clusters, whereas other cells exhibit a predominantly fusiform morphology (Wang et al. 2020; Caileau et al. 1974; Park et al. 2008; Keydar et al. 1979). After treatment with MAGCIT-MB, it is possible to observe a decrease in the number of adhered cells, and T-47D and A2780 lines underwent more significant changes when compared to MDA-MB-231 and non-tumoral cells. They presented a reduction in cell size, loss of focal adhesion points and characteristic cytoplasmic projections, especially after $48 \mathrm{~h}$ as shown in apoptosis process (Ziegler and Groscurth 2004; Häcker 2000; Srinivas et al. 2018). The MDA-MB-231 line exhibited morphological alterations in the first $24 \mathrm{~h}$ post-treatment, however, after 48 h, the cells recovered their original features (Fig. 3). Non-tumoral cells (HUVEC and HNTMC) also presented morphological alteration, but they occur to a lesser extent, showing a little reduction in the confluence and preservation of the characteristic cell structure (Additional file 6: Figure S5). Currently, it is known that tumor cells have baseline levels of ROS higher those of non-tumor cells (Reczek and Chandel 2017; Katz et al. 2012), which helps to promote the oxidative cell stress responsible for the cancer cell death. Evidently, like the other results presented, most normal cells survive after MAGCIT-MB treatment; therefore, the cells that remain on the plate do not activate the process of cell death and, consequently, maintain their original structure (Santos et al. 2017).

Scanning electron microscopy (SEM) indicates the reduction of tumor cell quantity and adhesion points, similarly to phase contrast light microscopy. The images show morphological changes on the cell's surface (after treatment) which acquires a more rounded and rough appearance when compared to the control. From Fig. 4, it is possible to observe that ovarian carcinoma cells reduce in size, whereas the breast 


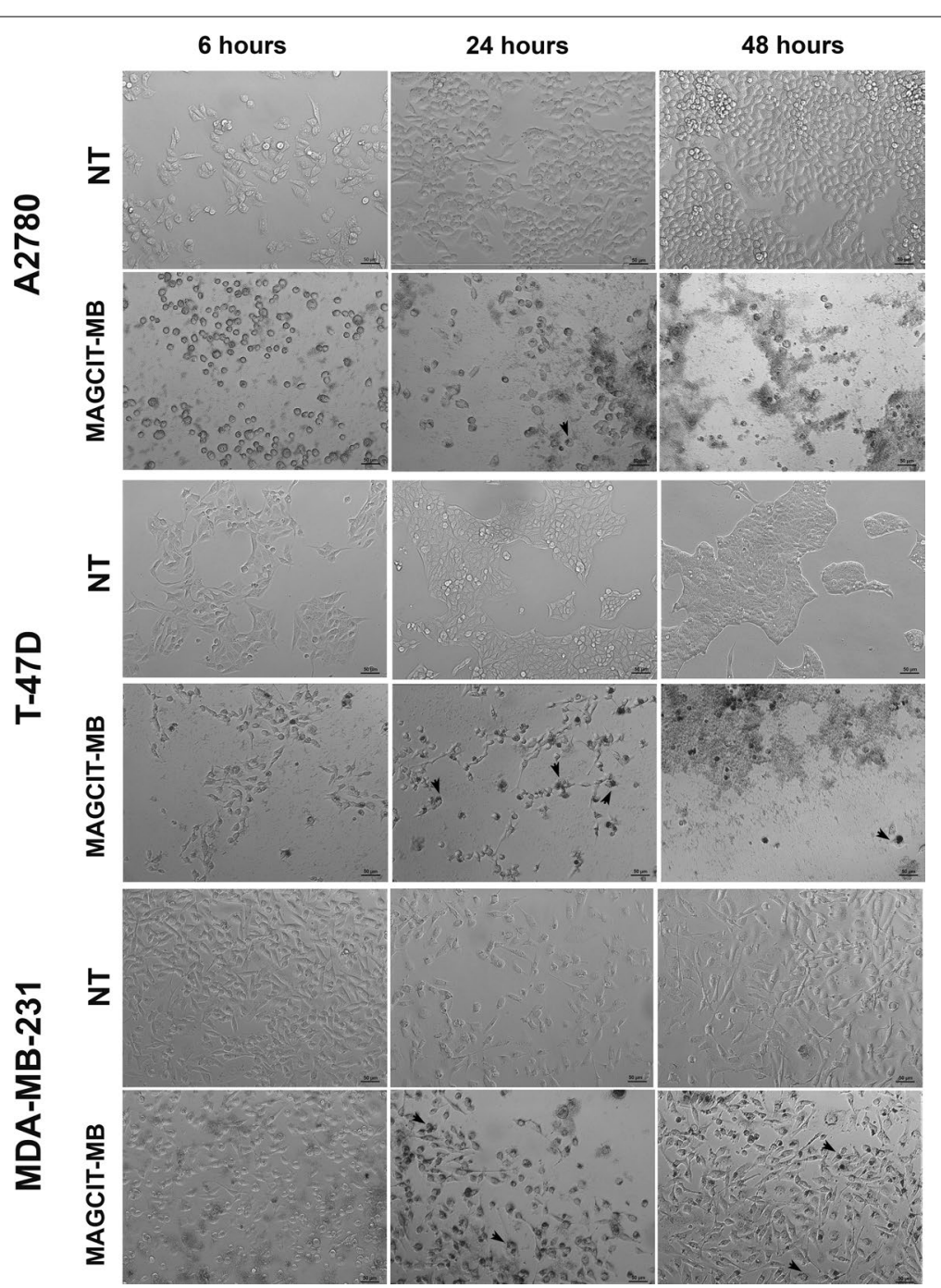

Fig. 3 Morphology of cancer cell lines after 6, 24 and $48 \mathrm{~h}$ of exposure to MAGCIT-MB treatment. Light microscopy images (phase contrast) by A2780, T-47D and MDA-MB-231 cell lines. Black arrows indicate MAGCIT-MB uptake by cells. Scale bar $=50 \mu \mathrm{m}$

adenocarcinoma lineage (T-47D) undergoes modification, and cells with various altered sizes can be observed.

\section{Cell death profile}

The type of cell death is an important process to understand, and it may contribute to elucidating mechanisms by which the nanocomplex interacts with the cell line under study (Keep et al. 2011; Lu et al. 2008; Wu et al. 2018; Castano et al. 2006). To evaluate the percentage of cells affected by apoptosis or necrosis, marking with fluorochromeconjugated annexin V and propidium iodide (PI) was performed. Apoptosis occurs when cells externalize a lipid found within the intracellular space, which could be measured by annexin V. Necrosis is assessed by means of the interaction between PI and the permeable membranes of cells in the process of death (Rocha et al. 2020). MAGCIT-MB 


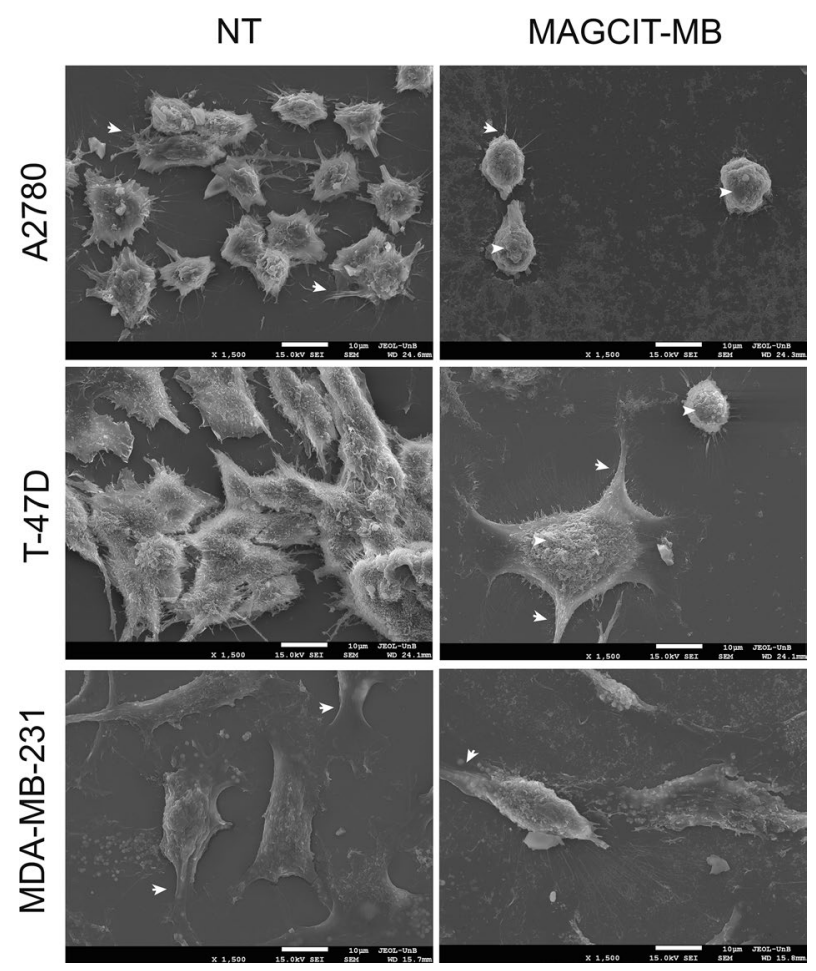

Fig. 4 Alteration of morphology of cancer cell lines after exposure to MAGCIT-MB treatment. Scanning electron micrograph (SEM). NT (cells without treatment) and cells treated with MAGCIT-MB after $48 \mathrm{~h}(0.78$ $\mu \mathrm{g} \mathrm{mL} \mathrm{L}^{-1}$ of MB). Arrows indicate cell adhesion points and arrowheads, changes in the cell surface. Scale $\mathrm{bar}=10 \mu \mathrm{m}$

treatment induced death of most cells from the A2780 and T-47D lines, by late apoptosis, which also has a small percentage (approximately 20\%) of necrosis-induced death. Observation of both apoptosis and necrosis cell death demonstrates the importance of future studies concerning the contribution of this nanocomplex to the activation of the immune system, since this process is very important for cancer therapy (Goldberg 2019; Keep et al. 2011). MDA-MB-231 was resistant to treatment, showing a small percentage of dead cells (approximately $29.5 \%$ of the total) with a necrosis death profile corresponding to $14 \%$. The analysis referring to non-tumor cells revealed that MAGIT-MB induces necrosis, at 29\%, and lytic death, at $12.8 \%$, in HUVEC cells. On the other hand, in HNTMC cells the highest percentage of death corresponds to early apoptosis, approximately $28 \%$ (Fig. 5 ).

\section{Internalization of MAGCIT-MB evaluated by TEM and endocytosis studies}

Previous studies have demonstrated the uptake of IONs by endocytic pathway in various cell types (Calero et al. 2015; Saadat et al. 2019; Zavisova et al. 2018; Youhannayee et al. 2018). To elucidate the endocytic pathway, we performed a cytometry analysis to evaluate the cells after treatment with the pathway inhibitors and MAGCIT-MB $(0.78 \mu \mathrm{g}$ $\mathrm{mL}^{-1}$ for $6 \mathrm{~h}$ ) (Rodrigues et al. 2020; Bansal et al. 2020). The results demonstrated that all cells have a statistically significant result for the inhibitor phenylarsine oxide. Phenylarsine oxide inhibits clathrin-mediated endocytosis, thereby showing that this mechanism 


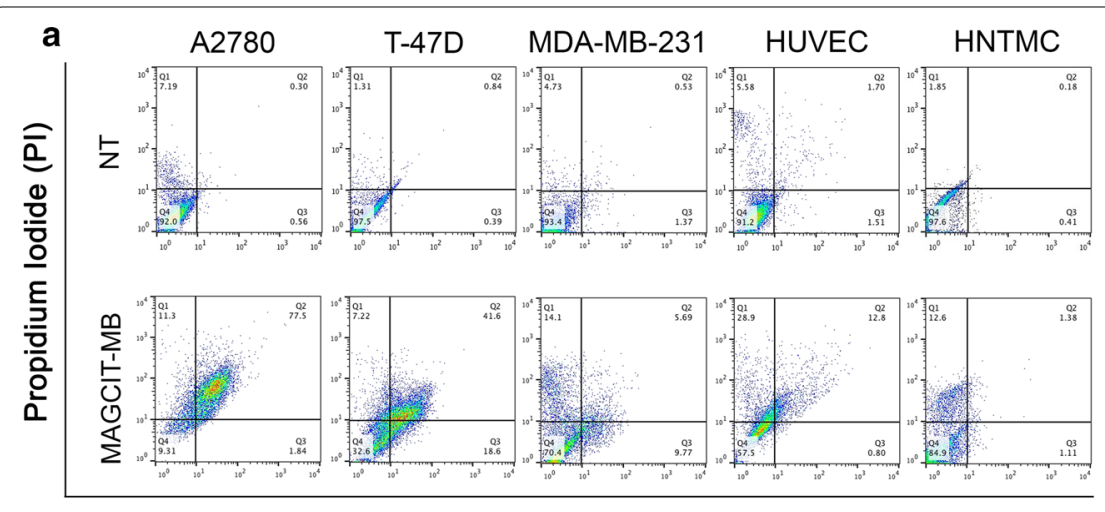

Annexin V

b
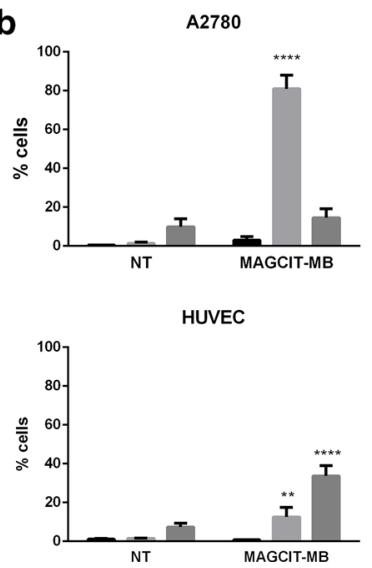

T-47D
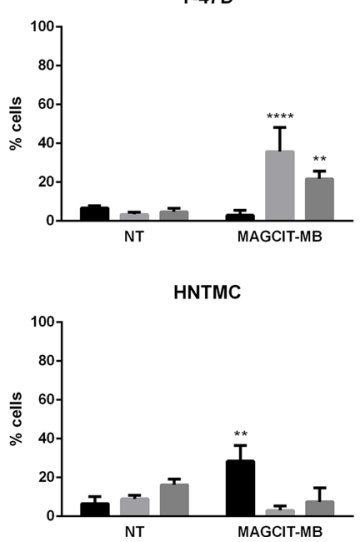

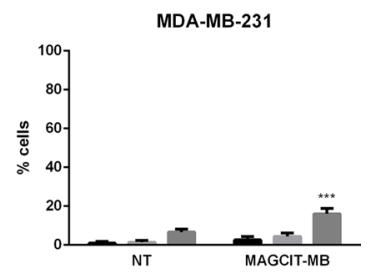

Fig. 5 Cell death profile after $48 \mathrm{~h}$ of MAGCIT-MB treatment $\left(0.78 \mu \mathrm{g} \mathrm{mL}{ }^{-1}\right.$ of $\left.\mathrm{MB}\right)$. a Dot plots representing the distribution of apoptotic and necrotic cells after dual staining with Annexin-V-FITC (horizontal axis) and propidium iodide (vertical axil). Results demonstrate live cells (lower left quadrant), early apoptosis (upper left quadrant), late apoptosis (upper right quadrant) and necrosis (lower right quadrant). b Percentage of cells presented. Groups: untreated cells (NT) and MAGCIT-MB. Data are presented as mean \pm SD from three experiments. ${ }^{* *} p<0.01,{ }^{* * *} p<0.001$ and ${ }^{* * *} p<0.0001$. ${ }^{*}$ Treatment compared to NT control

of cellular internalization is important for treatment with the proposed nanocomplex (Fig. 6a-f). A2780, T-47D and HUVEC exhibited significant results when pre-treated with the pinocytosis inhibitor (cytochalasin D) as well as MDA-MB-231 (Fig. 6a, b, e and $d$, respectively). There was no significant difference in the levels of internalization of MAGCIT-MB between cell lines (Additional file 7: Figure S6).

Corroborating the form of internalization observed through the cytometry test, the nanocomplex was accumulated within lysosomes and/or endosomes in the cytosol of the cancer cells as seen in the TEM images (Fig. 6f). Indeed, Calero et al. (2015) have demonstrated the internalization of IONs by clathrin-endocytic pathway in breast cancer cells (Calero et al. 2015). We have observed the internalization of MAGCIT-MB by all cells studied, with clathrin being its main endocytosis pathway. Studies prove that the mechanisms of endocytosis involved in the internalization of nanoparticles of approximately $50 \mathrm{~nm}$ are related to the clathrin pathway, corroborating other results which demonstrate that the MB agent is found at the lysosomal site (Nel et al. 2009; Suen and Chau 2013; Hiu et al. 2020). In addition to the invagination of the cell membrane present 


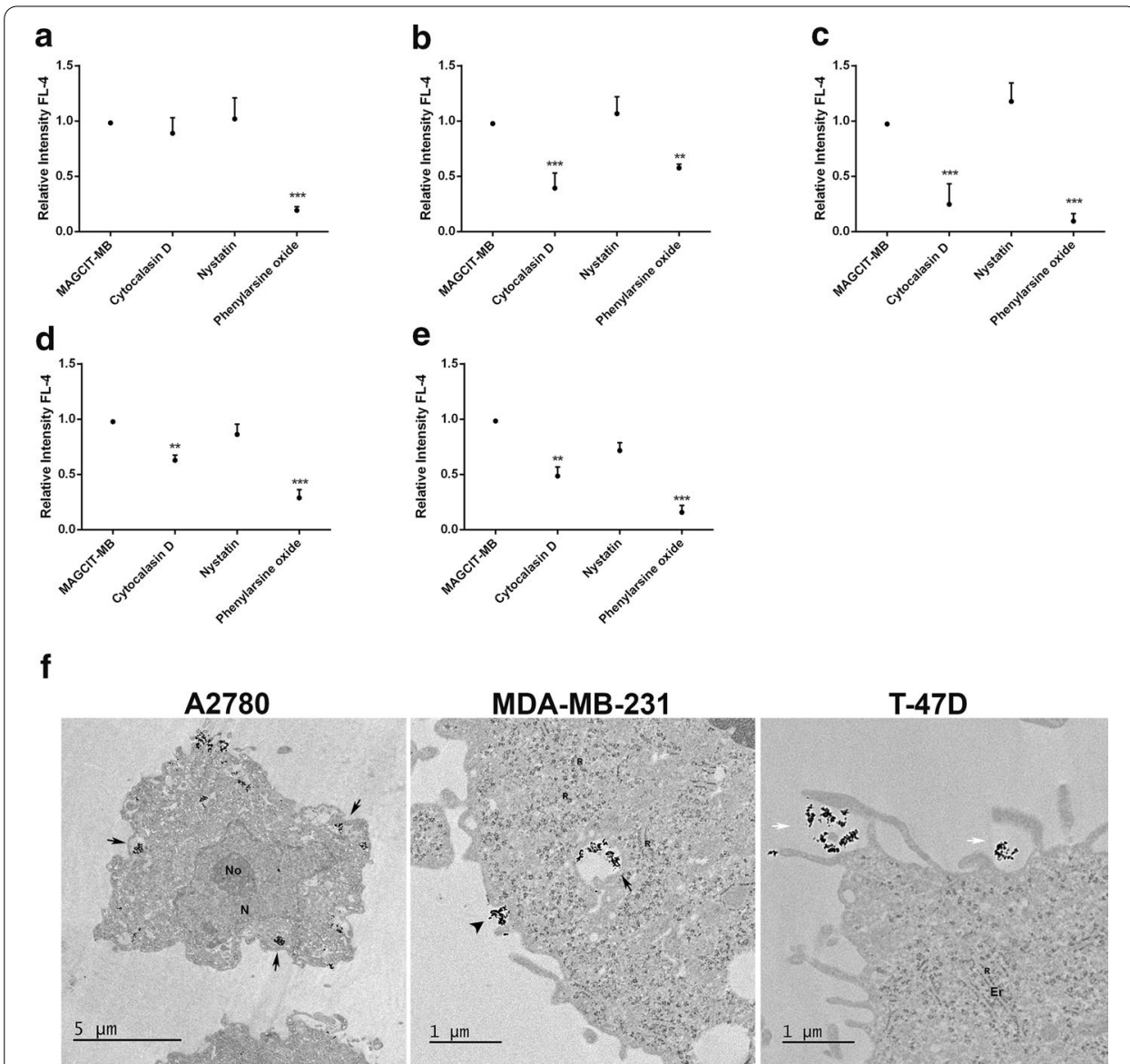

Fig. 6 MAGCIT-MB internalization in cancer cells after treatment with nanocomplex $\left(0.78 \mu \mathrm{g} \mathrm{mL}^{-1}\right.$ of $\mathrm{MB}$, 6 h). a Analysis of the uptake of MAGCIT-MB by cells a A2780, b T-47D, c MDA-MB-231, $\mathbf{d}$ HUVEC and $\mathbf{e}$ HNTMC pre-treated with different inhibitors of specific endocytosis pathways; cytochalasin D (pinocytosis), nystatin (caveolin) and phenylarsine oxide (clathrin), cells without exposure to inhibitors and incubated with MAGCIT-MB ( $6 \mathrm{~h}$ ) were used as a positive control. Data are presented as mean \pm SD from three experiments. ${ }^{* *} p<0.01,{ }^{* * *} p<0.001$. ${ }^{*}$ treatment compared to NT control. f Cancer cells ultrastructural images, obtained by Transmission Electron Microscopy (TEM), demonstrate the localization of MAGCIT-MB in lysosome/ endosomes (black arrow) in cancer cell lines, in addition to the presence of cytoplasmic prolongations indicating phagocytosis (white arrow). Black arrowhead indicates the invagination of membrane, $N$ nucleus, No nucleolus, Er Endoplasmic reticulum and $R$ ribosomes. Scale bars $=5 \mu \mathrm{m}$ and $1 \mu \mathrm{m}$

in the treated cell lines, expansion of the plasma membrane was also observed, which is an indication of MAGCIT-MB uptake by phagocytosis (Hiu et al. 2020). These facts also elucidate the presence of lysosomes/endosomes containing MAGCIT-MB. No nanoparticles were observed in the cell nucleus.

\section{Generating ROS in cancer lines}

It is already know that cancer cells are more sensitive to the presence of prooxidants due to their excessive ROS levels, which have a cytotoxic effect through apoptosis, necroptosis and autophagic cell death (Katz et al. 2012; Kim et al. 2019) Currently, the duality of ROS in promoting and interrupting the development of the carcinogenesis process has been observed (Hayes et al. 2020; Reczek and Chandel 2017). A low level of ROS is responsible for regulating cancer cell tumorigeneses, whereas a high level causes severe cellular damage. As 

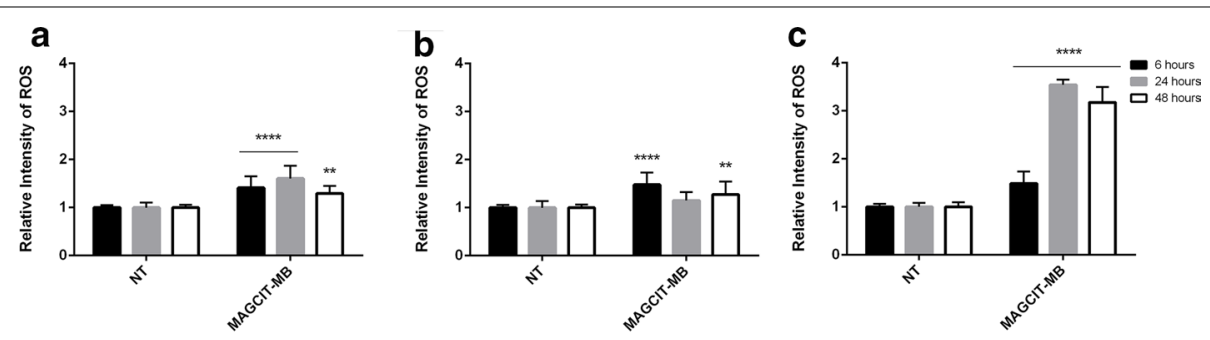

d

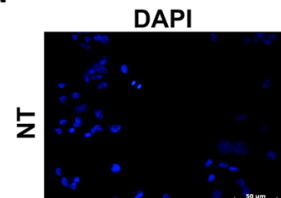

DCFH-DA

MERGE
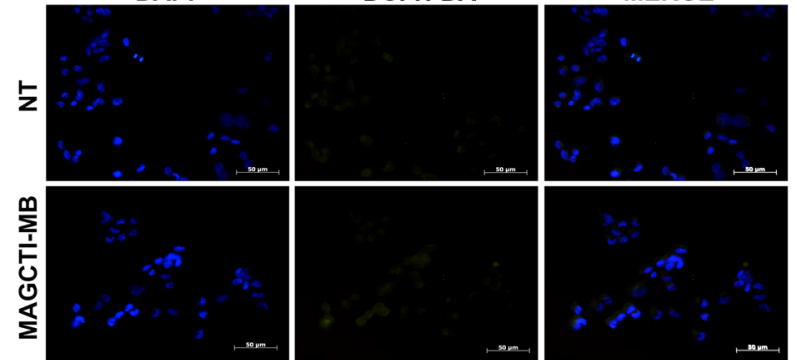

e

DAPI
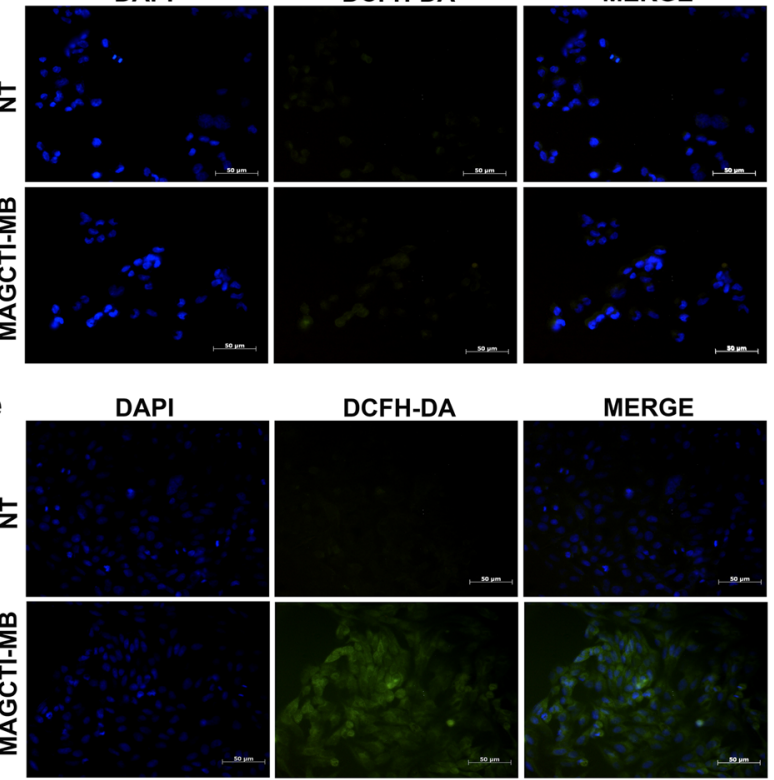

DCFH-DA

MERGE
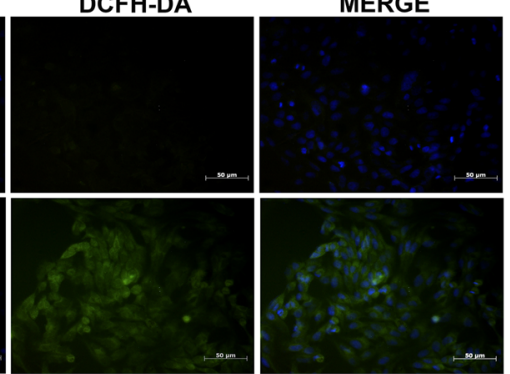

f

DAPI

DCFH-DA

MERGE
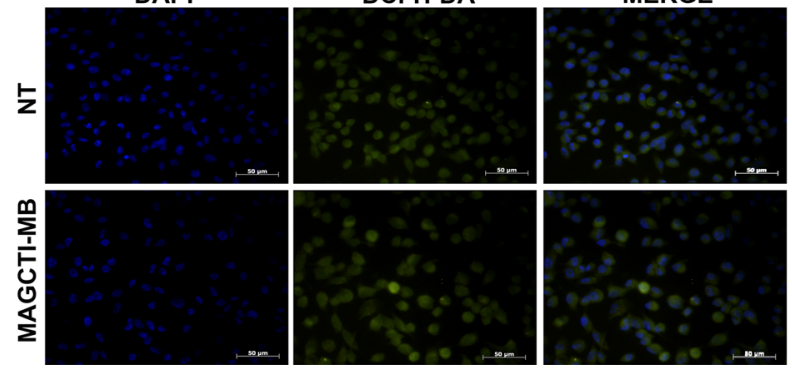

Fig. 7 Cancer cell lines ROS generation by DCFH-DA assay after MAGCIT-MB $\left(0.78 \mu \mathrm{g} \mathrm{mL}^{-1}\right.$ of MB) treatment. A2780 (a) T-47D (b) and MDA-MB-231 (c) ROS production after 6, 24 and $48 \mathrm{~h}$ of exposure to nanocomplex. Data are presented as mean \pm SD from three experiments. ${ }^{* *} p<0.01,{ }^{* * * *} p<0.0001$. ${ }^{*}$ Treatment compared to respective NT control. A2780 (d) T-47D (e) and MDA-MB-231 (f) DCFH-DA visualized by fluorescence microscopy after $6 \mathrm{~h}$ incubated with MAGCIT-MB. DNA counterstained with DAPI (blue) and cytoplasmic ROS generation with DCDH-DA (green). Scale bar $=50 \mu \mathrm{m}$

demonstrated in previous studies, MB has a therapeutic potential associated with ROS production (Tardivo et al. 2005; Youhannayee et al. 2018). Thus, the production of intracellular ROS was quantitatively determined by means of the $2^{\prime}, 7^{\prime}$-dichlorodihydrofluorescein diacetate (DCFH-DA) assay (Calero et al. 2015). Figure 7 shows that the developed nanocomplex increased the ROS production in all cancer cell lines, as observed in the green fluorescence microscopy images. In fact, it was seen that MAGCIT-MB is capable of inducing ROS production in the first $6 \mathrm{~h}$, similarly to that observed by spectrophotometric analysis (Wydra 
et al. 2015). In cell lines A2780 and MDA-MB-231, the ROS production achieved the highest value after $24 \mathrm{~h}$ of treatment with MAGCIT-MB $\left(0.78 \mu \mathrm{g} \cdot \mathrm{mL}^{-1}\right)$. Unlike the cells mentioned above, it was observed that in the T-47D cells a production peak occurs in the first 6 h.

The analysis referring to non-tumor cells showed that, for HUVEC, the greatest ROS production occurs in the first $6 \mathrm{~h}$ and for HNTMC, in $24 \mathrm{~h}$ (Additional file 7: Figure S6).

\section{Conclusion}

It was demonstrated that the MAGCIT-MB nanocomplex is capable of reducing the in vitro viability of two out of three cell lines, with a cell death driven by late apoptosis and necrosis. Like some other nanoparticles reported in the literature (Magro et al. 2020; Aghebati-Maleki et al. 2019), the nanoparticle MAGCIT has the potential to carry drugs, in view of its low toxicity in non-tumor cells, its high ratio of surface to volume, and its ability to target active compounds, avoiding their degradation and, thus, increasing therapeutic efficiency, as observed throughout this work. The occurrence of the two types of cell death demonstrates an important point for future studies aiming at cancer immunotherapy, because these two types not only lead to the destruction of local tumor cells, but also produce a possible local inflammatory response, caused by necrosis, leading to the activation of the immune system, thus obtaining a more effective and specific treatment (Goldberg 2019). In our study, the important activity of MAGCIT-MB related to the generation of reactive oxygen species and induction of oxidative stress in tumor cells (A2780 and T-47D) was observed, in which the ROS levels that arose after treatment with MAGCIT-MB were sufficient to reduce cell viability (Hosseinnzadeh and Khorsandi 2017). This is in contrast to the MDA-MB-231 cell line, where these levels have been shown to be effective only in decreasing cell proliferation. The results of a study of a triple-negative breast cancer line showed that the ROS levels increased by MAGCIT-MB were below the tolerable threshold, as well as other research with a different treatment (Chen et al. 2019), which demonstrate the maintenance of cell viability. The therapeutic specificity of MAGCIT-MB for the tumor cells was also observed, considering that for non-cancer cells similar results were achieved for treated and control experiments. In summary, we demonstrate that MAGCIT has an importance as a potential application in drug delivery systems, and it can be considered a platform for increasing MB cytotoxicity, specifically in breast and ovarian cancer. Thus, this suggests the potential of MAGCIT-MB to treat ovarian and breast cancer in in vivo studies.

\section{Materials and methods}

\section{Materials}

$2^{\prime}, 7^{\prime}$ Dichlorodihydrofluorescein diacetate, DAPI, Formvar solution, propidium iodide and Leibovitz's L-15 medium were bought from Sigma-Aldrich. Breast cancer lines (MDA-MB-231 and T-47D), an ovarian cancer line (A2780) and a non-tumor line (HUVEC) were acquired from the Rio de Janeiro Cell Bank (BCRJ). As primary culture of the human non-tumor mesenchymal cell (HNTMC) were obtained dental pulps from healthy volunteers who had previously signed a document of consent for approval by the human ethics committee of the University of Brasília (104934/2008). Dulbecco's modified Eagle's medium (DMEM), Roswell Park Memorial Institute medium 1640 (RPMI), 
fetal bovine serum (FBS), penicillin and streptomycin were purchased from Gibco, Invitrogen. Alamar Blue ${ }^{\mathrm{TM}}$, Annexin-V-FITC and Prolong Gold Antifade came from Thermo Fisher. Osmium tetroxide and uranyl acetate, Polysciences, USA.

\section{Methods}

\section{Elaboration of MAGCIT-MB nanocomplex}

MAGCIT were synthesized following a two-step process, briefly described as follows. Maghemite nanoparticles were first produced by alkaline coprecipitation of $\mathrm{Fe}$ (II)/Fe (III) $1: 2 \mathrm{~mol} / \mathrm{mol}$ solution at $100{ }^{\circ} \mathrm{C}$ as described by Massart (1981). In the second step, surface-functionalization was carried out by proper mixing of maghemite nanoparticles (90 mg L $\left.{ }^{-1}\right)$ with citric acid $(0.05 \mathrm{M}, \mathrm{pH}$ 6) under constant magnetic stirring at room temperature until complete homogenization. Afterward, the suspension was stirred in an ultrasonic bath $(80 \mathrm{~W})$ for $45 \mathrm{~min}$ and purified by dialysis against distilled water for $72 \mathrm{~h}$ (regenerated cellulose bags, cut-off $12.000 \mathrm{~g} \mathrm{~mol}^{-1}$ ) with periodic changing of water. The dialyzed suspension was submitted to sonication (ultrasonic probe Q700 Sonicator, QSonica, USA) for $10 \mathrm{~min}$ at $25 \%$ amplitude and the $\mathrm{pH}$ was adjusted to 6.6 with the addition of $\mathrm{NaOH}$ solution $(1 \mathrm{M})$. The MAGCIT-MB complex was then prepared by simple mixing of MAGCIT suspension and MB solution at different concentrations under constant magnetic stirring. Since MB and MAGCIT interact through electrostatic interaction, there was a narrow range of $\mathrm{MB}$ concentrations that could be loaded onto MAGCIT without causing irreversible agglomeration of the MAGCIT-MB nanocomplex. For a fixed concentration of MAGCIT $\left(3.84 \mu \mathrm{g} \mathrm{mL}^{-1}\right)$, the range of MB concentration was empirically determined between $53 \mu \mathrm{g} \mathrm{mL}^{-1}$ and $11 \mu \mathrm{g} \mathrm{mL}^{-1}$.

\section{Structural and morphological characterization of MAGCIT-MB}

The MB loading was evaluated by UV-Vis spectroscopy and Fourier transform infrared (FTIR) spectroscopy. UV-Vis spectra were registered with a Cary 5000 UV-Vis-NIR spectrophotometer (Agilent Technologies), in the range of $200-800 \mathrm{~nm}$, scan rate $0.1 \mathrm{~nm}$ $\mathrm{min}^{-1}$, and resolution of $1 \mathrm{~nm}$ FTIR. Spectra (in KBr pellets) were acquired with FTIR 6700 device (Thermo Fisher, USA) $\left(4000-500 \mathrm{~cm}^{-1}\right.$, resolution $0.1 \mathrm{~cm}^{-1}, 64$ scans). The hydrodynamic diameter and polydispersity were analyzed by dynamic light scattering (DLS), and zeta potentials by electrophoretic mobility in Zetasizer Nano ZS90 equipment (Malvern Instruments, United Kingdom). All measurements were carried out at 25 ${ }^{\circ} \mathrm{C}$ using ultrapure water as the solvent. MAGCIT-MB nanostructure was analyzed by transmission electron microscopy (TEM) (JEOL JEM 1011, JEOL, Japan) at $80 \mathrm{kV}$. Fluorescence spectra were acquired from aqueous MAGCIT, free MB and MAGCIT-MB samples using the Horiba Scientific model Fluorlog-3 spectrofluorometer using quartz cuvettes of $10 \mathrm{~mm}$ optical path with four polished windows. X-ray diffractometry of as synthesized maghemite nanoparticles was performed with a Bruker D8 Focus diffractometer $\left(\kappa=1.5418 \AA(\mathrm{Cu} \mathrm{K \alpha}), 0.1^{\circ} \mathrm{min}^{-1}\right.$, resolution $\left.0.5^{\circ}\right)$. 


\section{Cytotoxicity assay}

Experiments were carried out using two breast cancer lines (MDA-MB-231 and T-47D), an ovarian cancer line (A2780) a non-tumor line (HUVEC) and a human non-tumor mesenchymal cell (HNTMC), HUVEC, A2780 and T-47D cells were cultured in Dulbecco's modified Eagle medium (DMEM), DMEM-F12 and RPMI, respectively. All media were supplemented with $10 \%$ fetal bovine serum (FBS) and antibiotic (penicillin-streptomycin) at $1 \%$ and maintained at $37{ }^{\circ} \mathrm{C}, 5 \% \mathrm{CO}_{2}$. The MDA-MB-231 line was grown in L-15 medium, supplemented with a $10 \%$ FBS and $1 \%$ antibiotics and stayed in an incubator at $37{ }^{\circ} \mathrm{C}$ without the presence of $\mathrm{CO}_{2}$. Cell viability was determined using different concentrations of MAGCIT-MB (3.12; 1.56; $\left.0.78 ; 0.39 \mu \mathrm{g} \mathrm{mL}^{-1}\right)$ and free MB solution $\left(5.0 ; 2.5 ; 1.25 ; 0.62 \mu \mathrm{g} \mathrm{mL}^{-1}\right)$ for different times $(24,48$ and $72 \mathrm{~h})$. Cells were plated $\left(3 \times 10^{4}\right.$ per well) by being seeded into 96 -well cell culture plates and grown for $24 \mathrm{~h}$ at $37^{\circ} \mathrm{C}$. Afterward, cells were exposed to treatments for certain times. After incubation, fresh medium containing $10 \%$ of Alamar Blue ${ }^{\mathrm{TM}}$ reagent was added. Cells were further incubated for $2 \mathrm{~h}$ at $37^{\circ} \mathrm{C}$. Fluorescence was measured using a SpectraMax M5 spectrophotometer (Molecular Devices, USA) ( ex. 560; Кem. 590). For colony formation assays, cells were seeded in 6 -well plates at $1 \times 10^{5}$ cells per well overnight and then treated with MAGCIT-MB $\left(0.78 \mu \mathrm{g} \mathrm{mL}{ }^{-1}\right.$ of AM) for $48 \mathrm{~h}$. After that time, the surviving cells were washed and replated in 6 -well plates $\left(1 \times 10^{3}\right.$ cells/well $)$ and maintained for 5 days with medium renewal every 2 days. Colonies formed were fixed in methanol for $30 \mathrm{~min}$ and stained with $0.5 \%$ crystal violet for $30 \mathrm{~min}$. Images were obtained by LEICA M205 C stereoscope (Leica-Germany). The inhibitory concentration value ( $\left.\mathrm{IC}_{50}\right)$ and $95 \%$ confidence interval was derived from a nonlinear regression model based on sigmoidal dose response curve (variable slope) and computed using GraphPad Prism 5.0 (CA, USA).

\section{Annexin-V/propidium iodide staining analysis}

Cells $\left(5 \times 10^{5}\right.$ per well $)$ were dispersed in 12 -well plates and incubated with the MAGCIT-MB treatment $\left(0.78 \mu \mathrm{g} \mathrm{mL}^{-1}\right)$ for $48 \mathrm{~h}$. After the treatment, cells were washed with PBS and resuspended in a solution containing $100 \mu \mathrm{L}$ of blocking buffer $(10 \mathrm{mM}$ HEPES/ $\mathrm{NaOH}$ (pH 7.4), $140 \mathrm{mM} \mathrm{NaCl}$ and $2.5 \mathrm{mM} \mathrm{CaCl}_{2}$ ), $3 \mu \mathrm{L}$ of annexin-V-Alexa 488 (Invitrogen, USA) and propidium iodide $\left(5 \mu \mathrm{g} \mathrm{m}^{-1}\right)$ (Molecular Probes, USA). In this step, the cells were incubated for $15 \mathrm{~min}$, in the dark, at room temperature. Subsequently, $400 \mu \mathrm{L}$ of PBS buffer was added and 10.000 events of each sample were acquired by FACSCalibur flow cytometer, channels FL-1 and FL-2, (Becton Dickinson, USA) with the aid of CellQuest-Pro software.

\section{Cell morphology and ultrastructural analysis}

Cell morphology was visualized by the AxioVert light microscope (Zeiss, Germany) and images captured using the AxioVision 100 program, after treatment with MAGCIT-MB $\left(0.78 \mu \mathrm{g} \mathrm{mL}^{-1}\right)$ for 6,24 and $48 \mathrm{~h}$. For an ultrastructural analysis, $1 \times 10^{4}$ cells were dispersed in 6-well plates. After the treatment (MAGCIT-MB at $0.78 \mu \mathrm{g} \mathrm{mL}^{-1}$ for 3 and $48 \mathrm{~h}$ ), cells were washed with PBS and fixed overnight at $4{ }^{\circ} \mathrm{C}$ in solution containing $2 \%$ paraformaldehyde (v/v), 2\% glutaraldehyde (v/v) and $0.1 \mathrm{M}$ sodium cacodylate buffer $\mathrm{pH}$ 7.2. Afterward, cells were post-fixed, for $30 \mathrm{~min}$, in $2 \%$ osmium tetroxide (w/v) and 
$0.8 \%$ potassium ferricyanide ( $10 \mathrm{mM} \mathrm{CaCl}_{2}$ in $0.2 \mathrm{M}$ sodium cacodylate buffer). Samples were washed in distilled water and put into $0.5 \%$ uranyl acetate for $24 \mathrm{~h}$ at $4{ }^{\circ} \mathrm{C}$. The material was dehydrated in a graded acetone series (50-100\%) for 10 min each. Then, the samples were critical-point-dried (Balzers, CPD 030, Germany) from liquid $\mathrm{CO}_{2}$ and gold-sputtered (SCD 500, LEICA-Germany). Images were obtained by JSM-7001F (Jeol Japan) scanning electron microscope (SEM).

\section{Endocytosis study}

For the analysis of the endocytosis pathways, $1 \times 10^{4}$ cells were seeded in 12-well plates and treated with different inhibitors, namely cytochalasin D (pinocytosis), nystatin (caveolin) and phenylarsine oxide (clathrin) (Häcker 2000; Srinivas et al. 2018), for 30 min before treatment. The inhibition of the endocytosis pathway by ATP was carried out by incubating the samples at $4{ }^{\circ} \mathrm{C}$ for the same time applied to the other reagents. The MAGCIT-MB treatment $\left(0.78 \mu \mathrm{g} \cdot \mathrm{mL}^{-1}\right)$ was incubated for $6 \mathrm{~h}$ and then the cells were washed with PBS buffer and taken to the FACSCalibur flow cytometer (Becton Dickinson, USA) for data acquisition at channel FL-4. For an ultrastructural analysis, $1 \times 10^{4}$ cells were dispersed in 6-well plates. After the treatment (MAGCIT-MB at 0.78 $\mu \mathrm{g} \mathrm{mL}{ }^{-1}$ for 3 and $48 \mathrm{~h}$ ), cells were washed with PBS and fixed overnight at $4{ }^{\circ} \mathrm{C}$ in solution containing $2 \%$ paraformaldehyde (v/v), $2 \%$ glutaraldehyde $(\mathrm{v} / \mathrm{v})$ and $0.1 \mathrm{M}$ sodium cacodylate buffer $\mathrm{pH}$ 7.2. Afterward, cells were post-fixed, for $30 \mathrm{~min}$, in $2 \%$ osmium tetroxide $(\mathrm{w} / \mathrm{v})$ and $1.6 \%$ potassium ferricyanide $\left(10 \mathrm{mM} \mathrm{CaCl}_{2}\right.$ in $0.2 \mathrm{M}$ sodium cacodylate buffer). Samples were washed in distilled water and put into $0.5 \%$ uranyl acetate for $24 \mathrm{~h}$ at $4{ }^{\circ} \mathrm{C}$. The material was dehydrated in a graded acetone series $(50-100 \%)$ for 10 min each and embedded in Spurr resin. Ultrathin sections were obtained from an ultramicrotome UC6 (Leica, Germany) and observed in a Jeol 1011 transmission electron microscope (MET) at $80 \mathrm{kV}$.

\section{In vitro ROS production after treatment with MAGCIT-MB}

The evaluation of the production of ROS after treatment with MAGCIT-AM was performed by staining with $2^{\prime}, 7^{\prime}$ dichlorodihydrofluorescein diacetate (DCFH-DA) (0.01 $\mathrm{g} \mathrm{L}^{-1}$ for $\left.30 \mathrm{~min}\right)$ reagent of $1 \times 10^{4}$ cells. Cells were treated with MAGCIT-MB (0.78 $\mu \mathrm{g} \mathrm{mL}{ }^{-1}$ ) for $6 \mathrm{~h}$ and incubated with the marker reagent for $30 \mathrm{~min}$ before being taken to the washing process and analyzed in SpectraMax M5 (Molecular Devices, USA). For images by fluorescence microscopy, cells were plated under rounded laminates and, after treatment, cells were washed with PBS buffer $1 \mathrm{X}$ and fixed with $3.7 \%$ formaldehyde for $15 \mathrm{~min}$. DAPI staining was performed by incubating with reagent (300 $\mathrm{nM}$ for $7 \mathrm{~min}$ ). The coverslips were washed and mounted with Prolong Gold Antifade (ThermoFisher, USA).

\section{Cell proliferation analysis}

Proliferative activity of cells was measured by flow cytometry using CFSE reagent (succinimidyl ester carboxyfluorescein diacetate) labeled at the final concentration of $10 \mu \mathrm{M}$ 
(diluted in PBS/BSA 0.1\%). Previously labeled cells were cultured at a concentration of $1.5 \times 10^{5}$ cells per well in 12 -well plates. After adhesion, cells received treatment with MAGCIT-MB at $0.78 \mu \mathrm{g} \mathrm{mL}{ }^{-1}$ for $48 \mathrm{~h}$. After incubation, cells were removed from the plate and 20.000 events were analyzed using a FACSCalibur flow cytometer (Becton Dickinson, USA).

\section{Statistical analysis}

Analysis of variance (ANOVA) (two-way) was performed, followed by Bonferroni post hoc test for multiple comparisons and Student's test using the software GraphPad Prism 5.0 (CA, USA). Data were presented as mean value \pm SEM of at least three independent experiments. The significance level was defined as ${ }^{*} p<0.005,{ }^{* *} p<0.01,{ }^{* * * *} p<0.001$ and **** $p<0.0001$.

\section{Abbreviations}

MAGCIT-MB: Methylene blue with citrate-coated maghemite nanoparticles; MB: Methylene blue; MAGCIT: Solution of maghemite nanoparticles with citrate; ROS: Reactive oxygen species; PDT: Photodynamic therapy; IONs: Iron oxide nanoparticles; ZP: Zeta potential; HD: Hydrodynamic diameter; PDI: Polydispersity index; TEM: Transmission electron microscopy; FTIR: Fourier transform infrared spectroscopy; HNTMC: Human non-tumor mesenchymal cell; CFSE: Cell proliferation assay; $I C_{50}$ : Inhibitory concentration of 50\%; SEM: Scanning electron microscopy; PI: Propidium iodide; DCFH-DA: 2',7'-Dichlorodihydrofluorescein diacetate; BCRJ: Rio de Janeiro Cell Bank; DMEM: Dulbecco's modified Eagle's medium; RPMI: Roswell Park Memorial Institute medium 1640; FBS: Fetal bovine serum; DLS: Dynamic light scattering; ANOVA: Analysis of variance.

\section{Supplementary Information}

The online version contains supplementary material available at https://doi.org/10.1186/s12645-021-00083-x.

Additional file 1: Table S1. Physicochemical properties of the nanomaterial in culture medium.

Additional file 2: Figure S1. Suppressive effect on MB fluorescence and X-ray diffractogram. (a) X-ray diffractogram pattern of maghemite nanoparticles. (b) MB emission intensity. (c) Linear equation from the suppressive effect on $\mathrm{MB}$ fluorescence as a function of excitation with different wavelengths after formulation with different concentrations of MAGCIT.

Additional file 3: Figure S2. MDA-MB-231 proliferation assay with CFSE reagent after MAGCIT-MB treatment (48 h). Cells were exposed to MAGCIT $\left(3.84 \mu \mathrm{g} \mathrm{mL}^{-1}\right)$, free MB $\left(0.78 \mu \mathrm{g} \mathrm{mL} \mathrm{m}^{-1}\right)$ and MAGCIT-MB $\left(0.78 \mu \mathrm{g} \mathrm{mL}^{-1} \mathrm{of} \mathrm{AM}^{\mathrm{A}}\right)$ for $48 \mathrm{~h}$. The data represent the mean \pm SEM of three independent experiments in triplicate. ${ }^{*} p<0.05$. ${ }^{*}$ Treatment compared to NT control.

Additional file 4: Figure S3. Cytotoxicity of MAGCIT (3,84 $\left.\mu \mathrm{g} \cdot \mathrm{mL}^{-1}\right)$ after 24, 48 and 72 h. (a-e) A2780 (a) T-47D (b) MDA-MB-231 (c) HUVEC (d) and HNTMC (e) cell viability after exposure to MAGCIT. Bars represent cell viability in percentage after treatments at the indicated concentrations. The data represent the mean \pm SEM of three independent experiments in triplicate. ${ }^{*} p<0.05 ;{ }^{* *} p<0.01$ and ${ }^{* * *} p<0.001 .{ }^{*}$ Treatment compared to NT control.

Additional file 5: Figure S4. Colony formation and cell recovery assays of cancer cell lines in the long-term after 5 days post-treatment with MAGCIT-MB. Cells were treated with MAGCIT-MB $\left(0.78 \mu \mathrm{g} \mathrm{mL}^{-1}\right.$ of MB) for $48 \mathrm{~h}$ and the survivors were cultured for 5 days with only a medium change.

Additional file 6: Figure S5. Morphology of non-cancer cells (HUVEC and HNTMC) after 6, 24 and $48 \mathrm{~h}$ of exposure to MAGCIT-MB treatment. Light microscopy images (phase contrast). Black arrows indicate MAGCIT-MB uptake by cells. Scale bar $=50 \mu \mathrm{m}$.

Additional file 7: Figure S6. Internalization of MAGCIT-MB by cancer and non-cancer cell lines $\left(0.78 \mu \mathrm{g} \mathrm{mL}^{-1}\right.$ of MB). Data are presented as mean \pm SD from three experiments. No statistically significant difference between the groups.

Additional file 8: Figure S7. Non-tumoral cells ROS generation by DCFH-DA assay after 6, 24 and $48 \mathrm{~h}$ of exposure to nanocomplex $\left(0.78 \mu \mathrm{g} \mathrm{mL} \mathrm{m}^{-1}\right.$ of MB). HUVEC (a) and HNTMC (b) ROS production. Data are presented as mean \pm SD from three experiments. ${ }^{* * *} p<0.0001$. $^{*}$ Treatment compared to respective NT control. 


\section{Authors' contributions}

SNB, LGP and EP provided the conceptual framework for the study and made substantial contributions. ALGS was the principal investigator, performed the experiments and wrote the manuscript. LDM and NVC helped with nanoparticles and cytometry experiments. CLF contributed to the initial preparation of magnetic nanoparticles. All authors read and approved the final manuscript.

\section{Funding}

The authors gratefully acknowledge financial support from the Brazilian agencies: Coordenação de Aperfeiçoamento de Pessoal de Nível Superior (CAPES), Conselho Nacional de Desenvolvimento Científico e Tecnológico (CNPq), Financiadora de Estudos e Projetos (FINEP) and Fundação de Apoio à Pesquisa do Distrito Federal (FAPDF).

\section{Availability of data and materials}

The datasets used and/or analyzed during the study are available from the corresponding author on reasonable request.

\section{Ethics approval and consent to participate}

HNTMC from dental pulps obtained from healthy volunteers were collected in accordance with the Human Ethics Committee of the University of Brasília (Brasília, Brazil). Project Number 104934/2008.

\section{Consent for publications}

Not applicable.

\section{Competing interests}

The authors declare that they have no conflict of interests.

\section{Author details}

${ }^{1}$ Department of Cell Biology, Institute of Biological Sciences, University of Brasília, Brasília, DF, Brazil. ${ }^{2}$ Laboratory of Research on Polymers and Nanomaterials, Chemistry Institute, University of Brasília, Brasília, DF, Brazil. ${ }^{3}$ Department of Biochemistry and Tissue Biology Laboratory, Institute of Biology, University of Campinas, São Paulo, SP, Brazil.

Received: 9 January 2021 Accepted: 29 April 2021

Published online: 11 May 2021

\section{References}

Aghebati-Maleki A, Dolati S, Ahmade M, Baghbanzhadeh A, Asadi M, Fotouhi A, et al. Nanoparticles and cancer therapy: perspectives for application of nanoparticles in the treatment of cancers. J Cell Physiol. 2019;235:1962-72.

Ankamwar B, Lai TC, Huang JH, Liu RS, Hsiao M, et al. Biocompatibility of $\mathrm{Fe}_{3} \mathrm{O}_{4}$ nanoparticles evaluated by in vitro cytotoxicity assays using normal, glia and breast cancer cells. Nanotechnology. 2010;21:75-102.

Araujo JFDF, Arsalani S, Freire FL, Mariotto G. Novel scanning magnetic microscopy method for the characterization of magnetic nanoparticles. J Magn Magn Mat. 2020;499:166300.

Ayyanaar S, Balachandran C, Bhaskar RC, Kesavan MP, Aoki S, et al. ROS-responsive chitosan coated magnetic iron oxide nanoparticles as potential vehicles for targeted drug delivery in cancer therapy. Int J Nanomed. 2020;15:3333-46.

Bansal KK, Özliseli E, Saraogi GK, Rosenholm JM. Assessment of intracellular delivery potential of novel sustainable poly ( $\delta$-decalactone)-based micelles. Pharmaceutics. 2020;12:726.

Blanco E, Shen H, Ferrari M. Principles of nanoparticles design for overcoming biological barriers to drug delivery. Nat Biotechnol. 2015;33:941.

Boero IJ, Paravati AJ, Hou J, Gillespie EF, Shoenbunner A, et al. The impact of surgeons on the likelihood of mastectomy in breast cancer. Ann Surg. 2019;269:951-8.

Caileau R, Young R, Olivé M, Reeves WJ. Breast tumor cell lines from pleural effusions. J Natl Cancer Inst. 1974;53:661-74.

Calero M, Chiappi M, Carrillo AL, Rodríguez MJ, Chichón FJ, et al. Characterization of interaction of magnetic nanoparticles with breast cancer cells. J Nanobiotechnol. 2015;15:16.

Carneiro MLB, Peixoto RC, Joanitti GA, Oliveira RG, Telles LA, et al. Antitumor effect anf toxicity of free rhodium (II) citrate and rhodium (II) citrate-loaded maghemite nanoparticles in mice bearing breast cancer. J Nanobiotechnol. 2013;11:1-13.

Castano AP, Mroz P, Hamblin MR. Photodynamic therapy and anti-tumor immunity. Nat Rev Cancer. 2006;6:535-45.

Chen C, Wang S, Liu P. Deferoxamine enhanced mitochondrial iron accumulation and promoted cell migration in triplenegative MDA-MB-231 breast cancer cells via a ROS-dependent mechanism. Int J Mol Sci. 2019:20:1-16.

Cwalinski T, Polom W, Marano L, Roviello G, D'Angelo A, et al. Methylene blue-current knowledge, fluorescent properties, and its future use. J Clin Med. 2020;9:3538.

Fröhlich E. The role of surface charge in cellular uptake and cytotoxicity of medical nanoparticles. Int J Nanomed. 2012;7:5577-91.

Goldberg MS. Improving cancer immunotherapy through nanotechnology. Nat Rev Cancer. 2019;19:587-602.

Gomis-Tena J, Brown BM, Cano J, Trenor B, Yang PC, Saiz J, et al. When does the $\mathrm{IC}_{50}$ accurately assess the blocking potency of a drug? J Chem Inf Model. 2020;60:1779-90.

Gong Y, Ji P, Yang YS, Xie S, Yu TJ, et al. Metabolic-pathway-based subtyping of triple-negative breast cancer reveals potential therapeutic targets. Cell Metab. 2020;33(1):51-64.

Häcker G. The morphology of apoptosis. Cell Tissue Res. 2000;301:5-17.

Harush FO, Rozentur E, Benta S, Altschuler Y. Surface charge of nanoparticles determines their endocytic and transcytotic pathway in polarized MDCK cells. Biomacromol. 2008;9:435-43.

Hayes JD, Dinkova-Kostova AT, Tew DK. Oxidative stress in cancer. Cancer Cell. 2020;38:167-97. 
Hiu Y, Yi X, Wibowo D, Yang G, Middelberg APJ, et al. Nanoparticle elasticity regulates phagocytosis and cancer cell uptake. Sci Adv. 2020;6:eaaz4316.

Hosseinnzadeh R, Khorsandi K. Methylene blue, curcumin and ion paring nanoparticles effects on photodynamic therapy of MDA-MB-231 breast cancer cell. Photodiagn Photodyn Ther. 2017;1 8:284-94.

Izci M, Maksoudian C, Manshian BB, Soene SJ. The use of alternative strategies for enhanced nanoparticle delivery to solid tumors. Chem Rev. 2021;121:1746-803.

Katz JE, Zhang X, Attenkofer K, Chapman KW, Frandsen C, et al. Electron small polarons and their mobility in iron (oxyhydr)oxide nanoparticles. Science. 2012;337:1200-3.

Keep O, Galluzzi L, Lipinski M, Yuan J, Kroemer G. Cell death assays for drug discovery. Nat Rev Drug Discovery. $2011 ; 10: 221-37$

Keydar I, Chen L, Karby S, Weiss FR, Delarea J, et al. Establishment and characterization of a cell line of human breast carcinoma origin. Eur J Cancer. 1979;15:659-70.

Kim SJ, Kim HS, Seo YR. Understanding of ROS-inducing strategy in anticancer therapy. Oxid Med Cell Longev. 2019;2019:5381692.

Li Y, Gao Y, Zhang X, Guo H, Gao H. Nanoparticles in precision medicine for ovarian cancer: From chemotherapy to immunotherapy. Int J Pharm. 2020;591:119986.

Loutfy SA, Al-Ansary NA, Abdel-Ghani NT, Hamed AR, Mohamed MB, Craik JD, et al. Anti-proliferative activities of metallic nanoparticles in an in vitro breast cancer model. Asian Pac J Cancer Prev. 2019;16:6039-46.

Lu Y, Jiao R, Chen X, Zhong J, Ji J, et al. Methylene blue-mediated photodynamic therapy induces mitochondria-dependent apoptosis in HeLa Cell. J Cell Biochem. 2008;105:1461-560.

Magro M, Venerando A, Macone A, Canettieri G, Agostinelli E, Vianello F. Nanotechnology-based strategies to develop new anticancer therapies. Biomolecules. 2020:10:1-25.

Malhotra N, Lee JS, Liman RAD, Ruallo JMS, Villaflores OB, et al. Potential toxicity of iron oxide magnetic nanoparticles: a review. Molecules. 2020;25:3159.

Massart R. Preparation of aqueous magnetic liquids in alkaline and acidic media. IEEE Trans Magn. 1981;17:1247-8.

McKinney SM, Sieniek M, Godbole V, Godwin J, Antropova N, et al. International evaluation of an Al system for breast cancer screening. Nature. 2020;557:89-94.

Mirza S, Ahmad S, Shah MIA, Ateeq M. Magnetic nanoparticles: drug delivery and bioimaging applications. Metal Nanoparticles for Drug Delivery and Diagnostic Applications; 2020. p. 189-213.

Moore TL, Rodriguez-Lorenzo L, Hirsch V, Balog S, Urban D, Jud C, et al. Nanoparticle colloidal stability in cell culture media and impact on cellular interactions. Chem Soc Rev. 2015;44:6287-305.

Morales MP, Veintemillas-Verdaguer S, Montero MI, Serna CJ, Roig A, et al. Cherm Mater. 1999;1 1:3058.

Ovschinnikov OV, Evtukhova AV, Kondratenko TS, Smirnov MS, Khokhlov VY, et al. Manifestation of intermolecular interactions in FTIR spectra of methylene blue molecules. Vib Spectrosc. 2016;16:181-9.

Park YJ, Lee T, Ha J, Jung IM, Chung JK, et al. Effect of nicotine on human umbilical vein endothelial cells (HUVECS) migration and angiogenesis. Vascul Pharmacol. 2008;49:32-6.

Reczek C, Chandel NS. The two faces of reactive oxygen species in cancer. Annu Rev Cancer Biol. 2017;1:79-98.

Rocha M, Arcanjo R, Lopes C, Carneiro M, Souza A, et al. Modulation of fibronectin and laminin expression by Rhodium (II) citrate-coated maghemite nanoparticles in mice bearing breast tumor. Sci Rep. 2017;7:17904.

Rocha MCR, Silva PB, Radicchi MA, Andrade BYG, Oliveira JV, et al. Docetaxel-loaded solid lipid nanoparticles prevent tumor growth and lung metastasis of 4T1 murine mammary carcinoma cells. J Nanobiotechnol. 2020;18:43.

Rodrigues MC, Vieira LG, Horst FH, Araújo EC, Ganassin R, et al. Photodynamic therapy mediated by aluminium-phthalocyanine nanoemulsion eliminates primary tumors and pulmonary metastases in murine 4T1 breast adenocarcinoma model. J Photo. 2020;18:43.

Rozecholc A, Samouelian V, Warkus T, Gauthier P, Provencher D, et al. Green versus blue: randomized controlled trial comparing indocyanine green with methylene blue for sentinel lymph node detection in endometrial cancer. Gynecol Oncol. 2019;153:500-4.

Saadat M, Zahednezhad F, Miliani PZ, Heidari HR, Shahbazi-Mojarrad J, et al. Drug targeting strategies based on charge dependent uptake of nanoparticles into cancer cells. J Pharm Sci. 2019;22:191-220.

Sadeghloo AY, Khorsandi K, Kianmehr Z. Synergistic effect of photodynamic treatment and doxorubicin on triple negative breast cancer cells. Photochem Photobiol Sci. 2020;19:1580-9.

Sahu A, Choi WI, Lee JH, Tae G. Biomaterials graphene oxide mediated delivery of methylene blue for combined photodynamic and photothermal therapy. Biomaterials. 2013;34:1-10.

Santos AF, Terra LF, Wailemann RAM, Oliveira TC, Gomes VM, et al. Methylene blue photodynamic therapy induces selective and massive cell death in human breast cancer cells. BMC Cancer. 2017;17:194.

Santos MSC, Gouvêa AL, Moura LD, Paterno LG, Souza PEN, et al. Nanographene oxide-methylene blue as phototherapies platform for breast tumor ablation and metastasis prevention in a syngeneic orthotopic murine model. J Nanobiotechnol. 2018;16:9.

Schwaminger SP, Syhr C, Barensmeier S. Controlled synthesis of magnetic iron oxide nanoparticles: magnetite or maghemite. Curr Comput-Aided Drug Des. 2020;10:214.

Schwertmann U, Cornell RM. Iron oxides in the laboratory: preparation and characterization. New York: VCH Publishers; 1991.

Shojaee P, Niroomand-Oscuii H, Sefidgar M, Alinezhad L. Effect of nanoparticle size, magnetic intensity, and tumor distance on the distribution of the magnetic nanoparticles in a heterogeneous tumor microenvironment. J Magn Magn Mater. 2019;498:166089.

Siegel RL, Miller KD, Jemal A. Cancer statistics, 2018. Cancer J Clin. 2019;22:7-30.

Srinivas US, Tan B, Vellayappan BA, Jeyasekharan AD. ROS and the DNA damage response in cancer. Redox Biol. 2018;25:101084.

Suen WLL, Chau Y. Size-dependent internalization of folate-decorated nanoparticles via the pathways of clathrin and caveolar-mediated endocytosis in ARPE-19 cells. J Pharm Pharmacol. 2013;66:564-73. 
Tardivo JP, Giglio AD, Oliveira CS, Gabrielli DS, Junqueira HC, et al. Methylene blue in photodynamic therapy from basic mechanisms to clinical applications. Photodiagn Photodyn Ther. 2005;2:175-91.

Tran P, Lee SE, Kim DH, Pyo YC, Park JS. Recent advances of nanotechnology for the delivery of anticancer drugs for breast cancer treatment. J of Pharma Investig. 2019;50:261-70.

Wang J, Luo X, Li X, Lu W, Yang J, Hu Y, et al. Inhibition of cancer growth in vitro and in vivo by a novel ROS-modulating agent with ability to eliminate stem-like cancer cells. Cell Death Dis. 2017;8:e2887.

Wang X, Lin Y, Zheng Y. Antitumor effects of aconitine in A2780 cells via estrogen receptor $\beta$-mediated apoptosis, DNA damage and migration. Mol Med Rep. 2020;22:2318-28.

Widianti ME, Foote MB, Wang AZ. Chemoradiotherapy of human tumors: novel approaches from nanomedicine. Curr Pharm Des. 2019;12:323-30.

World Health Organization. Cancer. 2018. https://www.who.int/health-topics/cancer\#tab=tab_1. Accessed 4 Dec 2020.

Wu PT, Lin CL, Lin CW, Chang NC, Tsai WB, et al. Methylene-blue-encapsulated liposomes as photodynamic therapy nano agents for breast cancer cells. Nanomaterials. 2018;23:14.

Wydra RJ, Rychahou PG, Evers M, Anderson KW, Dziubla TD, et al. The role or ROS generation from magnetic nanoparticles in an alternating magnetic field on cytotoxicity. Acta Biomater. 2015;25:284-90.

Yang $Y$, Yang $Y$, Yang J, Zhao X, Wei X. Tumor microenvironment in ovarian cancer: function and therapeutic strategy. Front Cell Dev Biol. 2020;11(8):758.

Yaroslavisky AN, Feng X, Muzikansky A, Hamblin MR. Fluorescence polarization of methylene blue as a quantitative marker of breast cancer at the cellular level. Sci Rep. 2019;9:1-10.

Youhannayee M, Nakhaei-Rad S, Haghighi F, Klauke K, Janiak C, et al. Physical characterization, and uptake of iron oxide nanoparticles of different prostate cancer cells. J Magn Magn Mat. 2018;471:205-14.

Zavisova V, Koneracka M, Gabelova A, Svitkowa B, Ursinyova M, et al. Effect of magnetic coating on cell proliferation and uptake. J Magn Magn Mater. 2018;471:66-73.

Ziegler U, Groscurth P. Morphological features of cell death. News Physiol Sci. 2004;19:124-8.

\section{Publisher's Note}

Springer Nature remains neutral with regard to jurisdictional claims in published maps and institutional affiliations.

- fast, convenient online submission

- thorough peer review by experienced researchers in your field

- rapid publication on acceptance

- support for research data, including large and complex data types

- gold Open Access which fosters wider collaboration and increased citations

- maximum visibility for your research: over 100M website views per year

At BMC, research is always in progress.

Learn more biomedcentral.com/submissions 